\title{
Lacisediminihabitans profunda gen. nov., sp. nov., a member of the family Microbacteriaceae isolated from freshwater sediment
}

\author{
Ye Zhuo $\cdot$ Chun-Zhi Jin · Feng-Jie Jin • Taihua Li • Dong Hyo Kang • \\ Hee-Mock Oh $\cdot$ Hyung-Gwan Lee $\cdot$ Long Jin $\mathbb{D}$
}

Received: 14 August 2019/Accepted: 2 October 2019/Published online: 18 October 2019

(C) The Author(s) 2019

\begin{abstract}
A novel Gram-stain-positive bacterial strain, CHu50b-6-2 $2^{\mathrm{T}}$, was isolated from a $67-\mathrm{cm}-$ long sediment core collected from the Daechung Reservoir at a water depth of $17 \mathrm{~m}$, Daejeon, Republic of Korea. The cells of strain CHu50b-6-2 ${ }^{\mathrm{T}}$ were aerobic nonmotile and formed yellow colonies on R2A agar. The phylogenetic analysis based on 16S rRNA gene sequencing indicated that the strain formed a separate lineage within the family Microbacteriaceae, exhibiting $98.0 \%, 97.7 \%$ and $97.6 \%$ 16S rRNA gene
\end{abstract}

Ye Zhuo and Chun-Zhi Jin have contributed equally to this work.

The GenBank/EMBL/DDBJ accession numbers for sequences of strain $\mathrm{CHu} 50 \mathrm{~b}-6-2^{\mathrm{T}}$ generated in this study are as follows: MF770244 (16S rRNA), MK910353 (recA), and VRMG00000000 (whole genome sequence).

Electronic supplementary material The online version of this article (https://doi.org/10.1007/s10482-019-01347-8) contains supplementary material, which is available to authorized users.

\section{Y. Zhuo · F.-J. Jin · T. Li · L. Jin $(\bowtie)$}

College of Biology and the Environment, Co-Innovation Centre for Sustainable Forestry in Southern China,

Nanjing Forestry University, Nanjing 210037, China

e-mail: isacckim@kaist.ac.kr

C.-Z. Jin · D. H. Kang

Department of Bio-Molecular Science, KRIBB School of Bioscience, Korea University of Science and Technology (UST), 217 Gajeong-ro, Yuseong-gu, Daejeon, Republic of Korea sequence similarities to Glaciihabitans tibetensis KCTC $29148^{\mathrm{T}}$, Frigoribacterium faeni KACC $20509^{\mathrm{T}}$ and Lysinibacter cavernae DSM $27960^{\mathrm{T}}$, respectively. The phylogenetic trees revealed that strain CHu50b-6-2 ${ }^{\mathrm{T}}$ did not show a clear affiliation to any genus within the family Microbacteriaceae. The chemotaxonomic results showed $\mathrm{B} 1 \alpha$ type peptidoglacan containg 2, 4-diaminobutyric acid (DAB) as the diagnostic diamino acid, MK-10 as the predominant respiratory menaquinone, diphosphatidylglycerol, phosphatidylglycerol, and an unidentified glycolipid as the major polar lipids, anteiso- $\mathrm{C}_{15: 0}$, iso- $\mathrm{C}_{16: 0}$, and anteiso- $\mathrm{C}_{17: 0}$ as the major fatty acids, and a DNA G + C content of $67.3 \mathrm{~mol} \%$. The combined genotypic and phenotypic data showed that strain CHu50b-6-2 $2^{\mathrm{T}}$ could be distinguished from all genera within the family Microbacteriaceae and represents a novel genus, Lacisediminihabitans gen. nov., with the name Lacisediminihabitans profunda sp. nov., in the family Microbacteriaceae. The type

\footnotetext{
C.-Z. Jin · D. H. Kang

Industrial Biomaterial Research Center, Korea Research Institute of Bioscience and Biotechnology (KRIBB),

Daejeon 34141, Republic of Korea

H.-M. Oh · H.-G. Lee $(\bowtie)$

Cell Factory Research Centre, Korea Research Institute of Bioscience and Biotechnology (KRIBB), Daejeon 34141, Republic of Korea e-mail: trustin@kribb.re.kr
} 
strain is CHu50b-6-2 $2^{\mathrm{T}} \quad$ = KCTC $49081^{\mathrm{T}}=\mathrm{JCM}$ $32673^{\mathrm{T}}$ ).

Keywords Lacisediminihabitans .

Lacisediminihabitans profunda $\cdot$ CHu50b-6-2 .

Sediment

\section{Introduction}

Since Park et al. (1993) proposed the family $M i$ crobacteriaceae, 56 genera have been described validly in this family at the time of writing (http:// www.bacterio.net/; Parte 2018). Members of the family Microbacteriaceae are widely distributed in nature including soil, freshwater, groundwater, cyanobacterial mats, the rhizosphere and phyllosphere of plants, air and ice samples, ponds in Antarctica, sludge, seawater, sediment, seaweed, and seafood (Dias and Bhat 1962; Männistö et al. 2000; Reddy et al. 2003; Lee 2007; Kim et al. 2008; Kim and Lee 2011; Shin et al. 2011; Jang et al. 2012; Park et al. 2012; Schumann et al. 2012; Jin et al. 2013; Lai et al. 2015). During an investigation on iron and sulfur oxidizing microbial diversity in the sediment of a eutrophic freshwater reservoir (Jin et al. 2017), a strain designated $\mathrm{CHu} 50 \mathrm{~b}-6-2^{\mathrm{T}}$ was isolated from the freshwater sediment of the Daechung Reservoir. Herein, we describe the phylogenetic, genetic, phenotypic and chemotaxonomic characteristics of this novel strain, which is proposed to represent a new genus within the family Microbacteriaceae by using a polyphasic approach.

\section{Materials and methods}

Isolation, morphological and physiological characterization

Strain CHu50b-6- $2^{\mathrm{T}}$ was recovered from a $67-\mathrm{cm}-$ long

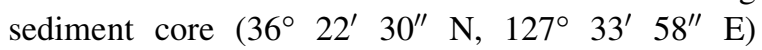
collected from the Daechung Reservoir at a water depth of $17 \mathrm{~m}$ in Daejeon, South Korea. $1 \mathrm{~g}$ sediment sample was applied to serial dilution method. A $100 \mu \mathrm{l}$ sub-sample $\left(10^{-6}\right.$ or $\left.10^{-7}\right)$ of the suspended material was spread onto modified 1/10 R2A agar $\left(\mathrm{L}^{-1}: 0.05 \mathrm{~g}\right.$ peptone, $0.05 \mathrm{~g}$ yeast extract, $0.05 \mathrm{~g}$ casamino acid, $0.05 \mathrm{~g}$ dextrose, $0.05 \mathrm{~g}$ soluble starch, $0.03 \mathrm{~g}$ $\mathrm{K}_{2} \mathrm{HPO}_{4}, 0.005 \mathrm{~g} \mathrm{MgSO}_{4}, 0.03 \mathrm{~g}$ sodium pyruvate, and $15 \mathrm{~g}$ agar) and incubated at room temperature $\left(25^{\circ} \mathrm{C}\right)$ for 4 weeks. One yellow colony, designated as CHu50b-6-2 ${ }^{\mathrm{T}}$, was isolated and subcultivated on R2A agar at $30{ }^{\circ} \mathrm{C}$ for further analysis. The colony characteristics were determined after growing for 5 days at $30{ }^{\circ} \mathrm{C}$ on R2A agar. Gram staining was performed using a Gram stain kit (Becton-Dickinson) and 3\% $\mathrm{KOH}$ solution. The cell morphology and motility were examined under a phase-contrast microscope (Nikon Eclipse 80i microscope, $1000 \times$ magnification) and a transmission electron microscope (CM20, Philips; Netherlands) after negative staining with $2 \%(\mathrm{w} / \mathrm{v})$ uranyl acetate using cells grown for $48 \mathrm{~h}$ on R2A agar.

The cell growth was checked on R2A agar, trypticase soy agar (TSA; Difco), Luria-Bertani (LB; Difco) medium, and nutrient agar. The growth temperature range was checked by incubating at 4,8 , $15,20,30,37$, and $45^{\circ} \mathrm{C}$ on R2A agar. Salt tolerance was performed by adding different concentrations of $\mathrm{NaCl}$ to $\mathrm{R} 2 \mathrm{~A}$ agar. The $\mathrm{pH}$ growth was determined in $\mathrm{R} 2 \mathrm{~A}$ broth with a $\mathrm{pH}$ range of 5-11 at intervals of $1 \mathrm{pH}$ unit. Different biological buffers were applied to adjust the $\mathrm{pH}$ values: $\mathrm{Na}_{2} \mathrm{HPO}_{4} / \mathrm{NaH}_{2} \mathrm{PO}_{4}$ buffer for pH 5-7 and $\mathrm{Na}_{2} \mathrm{CO}_{3} / \mathrm{NaHCO}_{3}$ buffer for $\mathrm{pH}$ 8-11 (Bates and Bower 1956; Gomori 1955). The oxidase activity was checked using $1 \%$ tetramethyl-pphenylenediamine (Tarrand and Groschel 1982), and the catalase activity was checked using $3 \% \mathrm{H}_{2} \mathrm{O}_{2}$. We used the API 20NE, ID $32 \mathrm{DN}$, API ZYM kits (bioMérieux), and Biolog GN2 MicroPlate to determine carbon source utilization and to do enzyme activity assays as well as additional physiological tests following the manufacturer's instructions. Duplicate antibiotic-susceptibility tests were conducted using filter-paper discs $(6 \mathrm{~mm})$ containing the following: amikacin $\quad\left(30 \mu \mathrm{g} \mathrm{ml}^{-1}\right), \quad$ ampicillin/sulbactam (20 $\left.\mathrm{g} \mathrm{ml}^{-1}, 1: 1\right)$, chloramphenicol $\left(30 \mu \mathrm{g} \mathrm{ml}^{-1}\right)$, erythromycin $\quad\left(30 \mu \mathrm{g} \mathrm{ml}^{-1}\right), \quad$ gentamicin $\left(30 \mu \mathrm{g} \mathrm{ml}^{-1}\right)$, kanamycin $\left(30 \mu \mathrm{g} \mathrm{ml}^{-1}\right)$, lincomycin $\left(15 \mu \mathrm{g} \mathrm{ml}^{-1}\right)$, nalidixic acid $\left(30 \mu \mathrm{g} \mathrm{ml}^{-1}\right)$, rifampicin (30 $\left.\mu \mathrm{g} \mathrm{ml}^{-1}\right)$, spectinomycin $\left(25 \mu \mathrm{g} \mathrm{ml}^{-1}\right)$, streptomycin $\left(25 \mu \mathrm{g} \mathrm{ml}^{-1}\right)$, teicoplanin $\left(30 \mu \mathrm{g} \mathrm{ml}^{-1}\right)$, tetracycline $\left(30 \mu \mathrm{g} \mathrm{ml}^{-1}\right)$, and vancomycin $\left(30 \mu \mathrm{g} \mathrm{ml}^{-1}\right)$. The discs were placed on R2A plates spread with a culture of strain $\mathrm{CHu} 50 \mathrm{~b}-6-2^{\mathrm{T}}$ and were then incu- 
bated at $30{ }^{\circ} \mathrm{C}$ for 2 days. Susceptibility was recorded as positive at zones with diameters greater than $10 \mathrm{~mm}$.

\section{Chemotaxonomic characterisation}

For fatty acid profiling, strain CHu50b-6- $2^{\mathrm{T}}$ was cultured on R2A agar for $48 \mathrm{~h}$ to the late exponential phase. Harvesting of the cell mass was standardized in the instruction of MIDI (http://www.microbialid.com/ PDF/TechNote_101.pdf). Separation and identification of the fatty acids were performed by GC (Hewlett Packard 6890), and the TSBA 6 database provided the Sherlock software 6.1. Extraction of isoprenoid quinone was carried out following the method described by Komagata and Suzuki (1987), and the analysis was done by HPLC (Shimadzu) with an YMC-Pack ODSA column. Extraction and identification of polar lipids were done using two-dimensional TLC following the method described by Tindall (1990). The isomer of diaminopimelic acid (DAP) in the cell wall was analyzed using the method described by Hasegawa et al. (1983). The cell-wall peptidoglycan was extracted and identified using TLC after hydrolysis with $6 \mathrm{M} \mathrm{HCl}$ at $100{ }^{\circ} \mathrm{C}$ for $18 \mathrm{~h}$ (Komagata and Suzuki 1987). Genomic DNA was extracted using a commercial genomic DNA-extraction kit (FastDNA ${ }^{\mathrm{TM}}$ SPIN kit). The purity of the extracted DNA was then examined on a ND2000 spectrometer (Nanodrop Technologies, Inc.). DNA G + C contents (mol\%) were analyzed by HPLC after hydrolysis as described by Tamaoka and Komagata (1984). Three reference strains were used: Glaciihabitans tibetensis KCTC $29148^{\mathrm{T}}$ was obtained from the KCTC (Korean Collection for Type Cultures), Frigoribacterium faeni KACC $20509^{\mathrm{T}}$ from the KACC (Korean Agricultural Culture Collection), and Lysinibacter cavernae DSM $27960^{\mathrm{T}}$ from the DSMZ (German Collection of Microorganisms and Cell Cultures).

\section{Molecular characterization}

The 16S rRNA gene was amplified by PCR as described previously (Ren et al. 2018) using the universal bacterial primer sets, 27F (5'-AGA GTT TGA TCM TGG CTC AG-3'; Escherichia coli position 8-27) and 1492R (5'-TAC GGY TAC CTT GTT ACG ACT T-3'; E. coli position 1492-1510, were used (Lane 1991). The purified PCR products then were sequenced with the BigDye Terminator v3.1 Cycle Sequencing kit (Applied Biosystems). Whole genome was sequenced via the Illumina HiSeq platform. The genome was assembled by the CLC assembler (CLC-Assembly-Cell-5.1.1), and the gene annotation was performed by the PATRIC 3.5.36 (hps://www.patricbrc.org). The average nucleotide identity (ANI) was calculated using OrthoANI tool in the EZBioCloud (Lee et al. 2016). To get the full 16S rRNA gene, the sequencing primers $27 \mathrm{~F}, 785 \mathrm{~F}\left(5^{\prime}\right.$ GGA TTA GAT ACC CTG GTA-3'), 800R (5'-TAC CAG GGT ATC TAA TCC-3'), and 1492R for the sequence analysis, were used (Lane 1991). The phylogenetic neighbors of strain CHu50b-6-2 $2^{\mathrm{T}}$ were identified, and the pairwise similarities of the $16 \mathrm{~S}$ rRNA gene sequences were calculated with EzBioCloud (Yoon et al. 2017). The retrieved 16S rRNA gene sequences were aligned using the CLUSTAL $\mathrm{X}$ program (Thompson et al. 1997). Evolutionary distances were calculated based on Kimura's two-parameter model (Kimura 1980). Phylogenetic trees were reconstructed with MEGA version 7.0 (Kumar et al. 2016) applying the neighbor-joining (Saitou and Nei 1987), maximum-likelihood (Felsenstein 1981) and maximum parsimony (Fitch 1971) algorithms. The bootstrap values were based on 1000 replicates (Felsenstein 1985). The housekeeping gene, recA gene encoding DNA recombinase A, was applied do delineate our strain more clearly from its close species. Housekeeping genes are useful for species identification as phylogenetic markers. The primer sets, rec A-F (5'-GTT CTC YTT RCC CTG NCC- $3^{\prime}$ ) and recA-R (5'-GAR TCS TCS GGW AAG ACB AC-3'), were used for amplifying and sequencing (Katayama et al. 2009). The PCR amplification conditions were as following: $95{ }^{\circ} \mathrm{C}$ for $5 \mathrm{~min}, 30$ cycles of $95^{\circ} \mathrm{C}$ for $1.5 \mathrm{~min}, 55^{\circ} \mathrm{C}$ for $1 \mathrm{~min}$ and $72{ }^{\circ} \mathrm{C}$ for $1 \mathrm{~min}$ and final extension for $10 \mathrm{~min}$ at $72{ }^{\circ} \mathrm{C}$. To determine genomic relatedness, DNA-DNA hybridisation experiment was carried out between strain CHu50b-6$2^{\mathrm{T}}$ and type strains of G. tibetensis, F. faeni and $L$. cavernae, which showed over $97 \%$ of $16 \mathrm{~S}$ rRNA gene similarities to novel strain. The hybridisation test was carried out as described by Ezaki et al. (1989), and salmon sperm DNA (Sigma; D7656) was used as a control. 


\section{Results and discussion}

Strain CHu50b-6-2 ${ }^{\mathrm{T}}$ formed yellow colonies within $48 \mathrm{~h}$ on R2A agar at $30^{\circ} \mathrm{C}$. While cell growth occurred at temperatures ranging from 4 to $30^{\circ} \mathrm{C}$, no growth was observed at $37{ }^{\circ} \mathrm{C}$. Growth was observed at $\mathrm{pH} 6$ to 10 , but no growth was observed at $\mathrm{pH} 5$ or 11 . The colonies were convex and circular with entire edges. The cells were found to be Gramstain-positive, oxidase-negative, catalase-positive, non-motile, and rod shaped (Supplementary Fig. 1). The cells were observed to assimilate $N$-acetyl-Dgalactosamine, $\mathrm{N}$-acetyl-glucosamine, L-arabinose, 2,3-butanediol, D-cellobiose, dextrin, D-fructose, Dgalactose, D-gluconic acid, D-glucose, glycerol, inosine, inositol, $\alpha$-keto butyric acid, DL-lactate, lactulose, maltose, mannitol, D-melibiose, pyruvic acid methyl ester, D-raffinose, rhamnose, D-ribose, D-sorbitol, sucrose, turanose, thymidine, uridine, and xylitol but not the rest (API 20NE, API ID 32GN test strips and Biolog GN2 MicroPlate). The cells were found to be positive for the following enzyme activities (API ZYM test strip): acid phosphatase, cystine arylamidase, esterase (C4), esterase lipase (C8), $\alpha$-galactosidase, $\beta$-galactosidase, $\alpha$-glucosidase, $\beta$-glucosidase, leucine arylamidase, naphtol-AS-BI-phosphohydrolase, and valine arylamidase but the cells were found to be negative for the following enzyme activities: $N$ acetyl- $\beta$-glucosaminidase, alkaline phosphatase, $\alpha$ chymotrypsin, $\alpha$-fucosidase, $\beta$-glucuronidase, lipase (C14), $\alpha$-mannosidase and trypsin (Table 1). The cells were found to be susceptible to amikacin $\left(30 \mu \mathrm{g} \mathrm{ml}^{-1}\right)$, chloramphenicol $\left(30 \mu \mathrm{g} \mathrm{ml}^{-1}\right)$, erythromycin $\left(30 \mu \mathrm{g} \mathrm{ml}^{-1}\right)$, kanamycin $\left(30 \mu \mathrm{g} \mathrm{ml}^{-1}\right)$, lincomycin $\left(15 \mu \mathrm{g} \mathrm{ml}^{-1}\right)$, rifampicin $\left(30 \mu \mathrm{g} \mathrm{ml}^{-1}\right)$, spectinomycin $\quad\left(25 \mu \mathrm{g} \mathrm{ml}^{-1}\right), \quad$ streptomycin $\left(25 \mu \mathrm{g} \mathrm{ml}^{-1}\right)$, teicoplanin $\left(30 \mu \mathrm{g} \mathrm{ml}^{-1}\right)$, and vancomycin $\left(30 \mu \mathrm{g} \mathrm{ml}^{-1}\right)$ but resistant to ampicillin/sulbactam $\left(1: 1 ; \quad 20 \mu \mathrm{g} \mathrm{ml}^{-1}\right), \quad$ nalidixic acid $\left(30 \mu \mathrm{g} \mathrm{ml}^{-1}\right)$, gentamicin $\left(30 \mu \mathrm{g} \mathrm{ml}^{-1}\right)$, and tetracycline $\left(30 \mu \mathrm{g} \mathrm{ml}^{-1}\right)$. Strain CHu50b-6-2 ${ }^{\mathrm{T}}$ could be differentiated from the closest species $G$. tibetensis by assimilating $\mathrm{N}$-acetyl-glucosamine, L-arabinose, Dglucose, maltose, and D-mannitol and by activities of nitrate reduction, arginine dihydrolase, oxidase, $\alpha$ chymotrypsin, lipase (C14), and trypsin; from $F$. faeni by assimilating $N$-acetyl-glucosamine and not assimilating citrate, by activities of arginine dihydrolase, alkaline phosphatase, and motility; from $L$. cavernae by not assimilating gluconate and D-mannose, by activities of nitrate reduction, arginine dihydrolase, oxidase, cystine arylamidase, $\alpha$-galactosidase, $\beta$ galactosidase, and lipase (C14).

The draft genome sequence of strain CHu50b-6-2 $2^{\mathrm{T}}$ was deposited at DDBJ/EMBL/GenBank with the accession number PRJNA559971. The draft genome of strain CHu50b-6-2 ${ }^{\mathrm{T}}$ was of 4,022,930 bp, containing 175 contigs, of which the largest was of 845,903 bp. The genome encoded 3975 genes, including 48 tRNAs and 7 rRNAs. The N50 value was 413,391 and the sequencing depth of coverage was $570 X$. The DNA G $+\mathrm{C}$ content calculated from the draft genome sequence was $67.3 \mathrm{~mol} \%$ (Table S1). The ANI values of strain CHu50b-6-2 $2^{\mathrm{T}}$ with $G$. tibetensis MP203 ${ }^{\mathrm{T}}$ and F. faeni $801^{\mathrm{T}}$ were 73.1 and 73.4, respectively.

The almost-complete 16S rRNA gene sequence (approximately $1461 \mathrm{nt}$ ) of strain CHu50b-6-2 ${ }^{\mathrm{T}}$ was compared with those of representative species within the family Microbacteriaceae. Strain CHu50b-6-2 $2^{\mathrm{T}}$ showed over 97\% 16S rRNA gene sequence similarities with G. tibetensis, F. faeni, L. cavernae, F. endophyticum, Parafrigoribacterium mesophilum, Cryobacterium arcticum, F. salinisoli, and Homoserinimonas aerilata, and less than $97 \%$ with the remaining members of the family Microbacteriaceae. According to maximum-likelihood, neighbour-joining, and maximum-parsimony tree analysis (Fig. $1 \&$ Supplementary Fig. S2), the isolate was phylogenetically distinct from closely related members of the family Microbacteriaceae, especially with G. tibetensis, F. faeni, L. cavernae with which it showed $98.0 \%$, $97.7 \%$, and $97.6 \% 16 \mathrm{~S}$ rRNA gene sequence similarities, respectively. And the genomic delineation between strain CHu50b-6-2 ${ }^{\mathrm{T}}$ and the type strains of G. tibetensis, F. faeni, and L. cavernae was supported by the DNA-DNA relatedness (the mean of triplicate experiments) data, for which our novel isolate showed DNA-DNA relatedness values of $31.2 \%$ (reciprocal $29.2 \%$ ), $29.7 \%$ (reciprocal $33.1 \%$ ), and $22.5 \%$ (reciprocal 24.9\%) with G. tibetensis KCTC $29148^{\mathrm{T}}, F$. faeni KACC $20509^{\mathrm{T}}$ and L. cavernae DSM $27960^{\mathrm{T}}$, respectively. For clearer delineation, the housekeeping gene, $r e c \mathrm{~A}$ gene was applied as phylogenetic marker. The recA gene sequence of CHu50b-6-2 $2^{\mathrm{T}}$ had $88.8 \%, 88.2 \%, 86.2 \%, 85.9 \%$, and $85.4 \%$ similarities with Clavibacter michiganensis VKM Ac-1403 ${ }^{\mathrm{T}}$, Subtercola boreus DSM $13056^{\mathrm{T}}$, Rathayibacter 
Table 1 Phenotypic and chemotaxonomic characteristics distinguishing strain CHu50b-6-2 ${ }^{\mathrm{T}}$ from three closest members

\begin{tabular}{|c|c|c|c|c|}
\hline Characteristics & 1 & 2 & 3 & 4 \\
\hline Isolation source & Sediment & Glacier water & Hay dust & Soil \\
\hline Morphology & Rod & Short rod & Irregular rod & Rod \\
\hline Colony colour & Yellow & Pale yellow & Pale yellow & Brilliant yellow \\
\hline Motility & - & - & + & - \\
\hline Nitrate reduction & + & - & - & - \\
\hline Oxidase/catalase & $-1+$ & $+/+$ & $-1+$ & $+/+$ \\
\hline Arginine dihydrolase & - & + & + & + \\
\hline $\begin{array}{l}\mathrm{NaCl} \text { tolerance range } \\
(\mathrm{w} / \mathrm{v}, \%)\end{array}$ & $0-2$ & $0-4.5^{\mathrm{a}}$ & $0-7^{\mathrm{b}}$ & $0-5^{\mathrm{c}}$ \\
\hline \multicolumn{5}{|l|}{ Carbon utilization: } \\
\hline$N$-Acetyl-glucosamine & $\mathrm{w}$ & - & - & + \\
\hline L-Arabinose & + & - & + & + \\
\hline Citrate & - & - & + & - \\
\hline Gluconate & - & - & - & + \\
\hline D-Glucose & + & - & + & + \\
\hline Maltose & + & - & + & + \\
\hline D-Mannitol & + & - & + & + \\
\hline D-Mannose & - & - & - & + \\
\hline \multicolumn{5}{|l|}{ Enzyme activity: } \\
\hline Alkaline phosphatase & - & - & + & - \\
\hline$\alpha$-Chymotrypsin & - & $\mathrm{w}$ & + & - \\
\hline Cystine arylamidase & + & + & + & - \\
\hline$\alpha$-Galactosidase & + & + & + & - \\
\hline$\beta$-Galactosidase & + & + & + & - \\
\hline Lipase (C14) & - & $\mathrm{w}$ & - & $\mathrm{w}$ \\
\hline Trypsin & - & $\mathrm{w}$ & - & - \\
\hline Respiratory quinones & MK-10 & MK-11, $10,9^{\mathrm{a}}$ & MK-9b & $\mathrm{MK}-11,10,9^{\mathrm{c}}$ \\
\hline Polar lipids & $\begin{array}{l}\text { DPG, PG, GL, L1, } \\
\text { L2, L3 }\end{array}$ & $\begin{array}{l}\text { DPG, PG, GL, L1, L2, } \\
\text { L3, L4 }\end{array}$ & $\begin{array}{l}\mathrm{DPG}, \mathrm{PG}, \mathrm{GL}, \\
\mathrm{L}^{\mathrm{c}}\end{array}$ & $\begin{array}{l}\text { DPG, PG, GL, L1, L2, PL1, PL2, } \\
\text { PL3, PL4 }\end{array}$ \\
\hline $\begin{array}{l}\text { DNA G }+ \text { C content } \\
(\mathrm{mol} \%)\end{array}$ & 67.3 & $64.1^{\mathrm{a}}$ & $71^{\mathrm{b}}$ & $62.6^{\mathrm{c}}$ \\
\hline
\end{tabular}

Strains: 1, CHu50b-6-2 ${ }^{\mathrm{T}}$; 2, G. tibetensis KCTC $29148^{\mathrm{T}} ; 3$, F. faeni KACC $20509^{\mathrm{T}}$; 4, L. cavernae DSM $27960^{\mathrm{T}}$. All data were from this study, unless indicated. All strains were observed to be positive for activities of acid phosphatase, esterase (C4), esterase lipase (C8), $\alpha$-glucosidase, $\beta$-glucosidase, leucine arylamidase, naphthol-AS-BI-phosphohydrolase, and valine arylamidase; All strains were observed to be negative for activities of indole production, glucose acidification, urease, gelatin hydrolysis, $N$-acetyl- $\beta$ glucosaminidase, $\alpha$-fucosidase, $\beta$-glucuronidase, and $\alpha$-mannosidase; carbon assimilation of adipate, caprate, malate, and phenyl acetate. DPG, diphosphatidylglycerol; PG, phosphatidylglycerol; GL, unidentified glycolipid; PL, unidentified phospholipid; L, unidentified lipid. - , negative; + , positive; w, weakly positive

${ }^{\mathrm{a}}$ Data taken from Li et al. (2014)

${ }^{\text {b}}$ Kämpfer et al. (2000)

${ }^{\mathrm{c}}$ Tuo et al. (2015)

rathayi DSM $7485^{\mathrm{T}}, F$. faeni $\mathrm{KACC} 20509^{\mathrm{T}}$, and $G$. tibetensis KCTC $29148^{\mathrm{T}}$ respectively. Overall, phylogenetic analyses based on $16 \mathrm{~S}$ rRNA, recA genes and UPGMA dendrogram based on the ANI values of genomic sequences revealed groups that are in good agreement with the currently recognized genera 


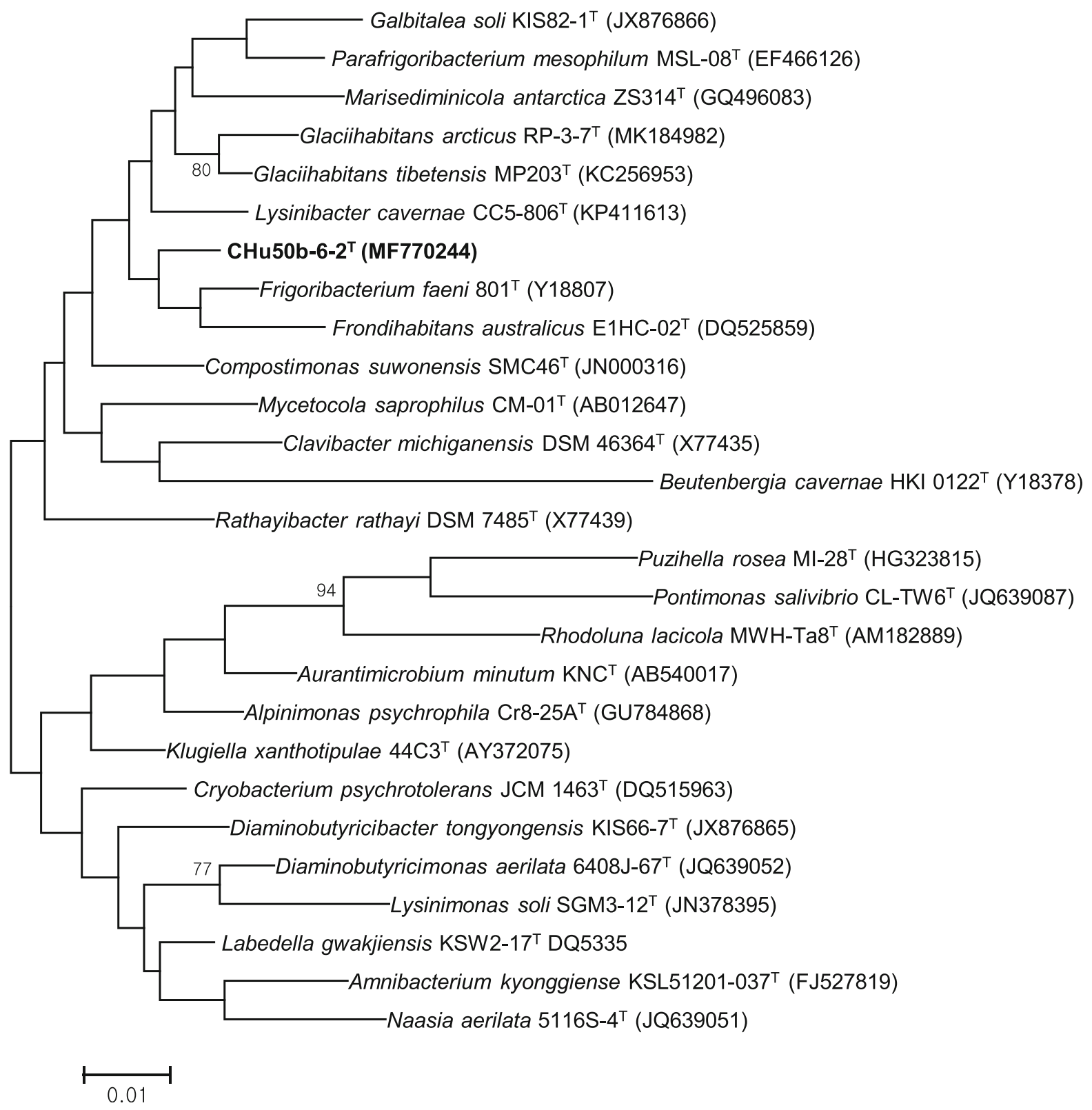

Fig. 1 Phylogenetic tree based on 16S rRNA gene sequences using maximum-likelihood method showing position of strain CHu50b-6-2 ${ }^{\mathrm{T}}$ among type species within the family Microbacteriaceae. Numbers at branching points refer to bootstrap values

(Figs. 1, 2, 3). The lower DNA-DNA hybridization values together with phylogenetic analysis revealed that strain CHu50b-6-2 ${ }^{\mathrm{T}}$ could not be clearly assigned to any species of the genus Glaciihabitans, Frigoribacterium, and Lysinibacter.

The $\mathrm{G}+\mathrm{C}$ content of the genomic DNA was $67.3 \mathrm{~mol} \%$, and the major fatty acids were anteiso-
(1000 resamplings, only values above $70 \%$ shown). Beutenbergia cavernae HKI $0122^{\mathrm{T}}$ (Y18378) was used as an outgroup. Bar, 1 substitutions per $100 \mathrm{nt}$

$\mathrm{C}_{15: 0}(46.6 \%)$, iso- $\mathrm{C}_{16: 0}(29.7 \%)$, and anteiso- $\mathrm{C}_{17: 0}$ $(14.5 \%)$ (Table 2). The major predominant respiratory menaquinone was MK-10. The polar lipids consisted of diphosphatidylglycerol (DPG), phosphatidylglycerol (PG), an unidentified glycolipid (GL), and three unidentified lipids (L1, L2, and L3) (Supplementary Fig. 3). It is noteworthy that strain CHu50b-6- $2^{\mathrm{T}}$ had a 


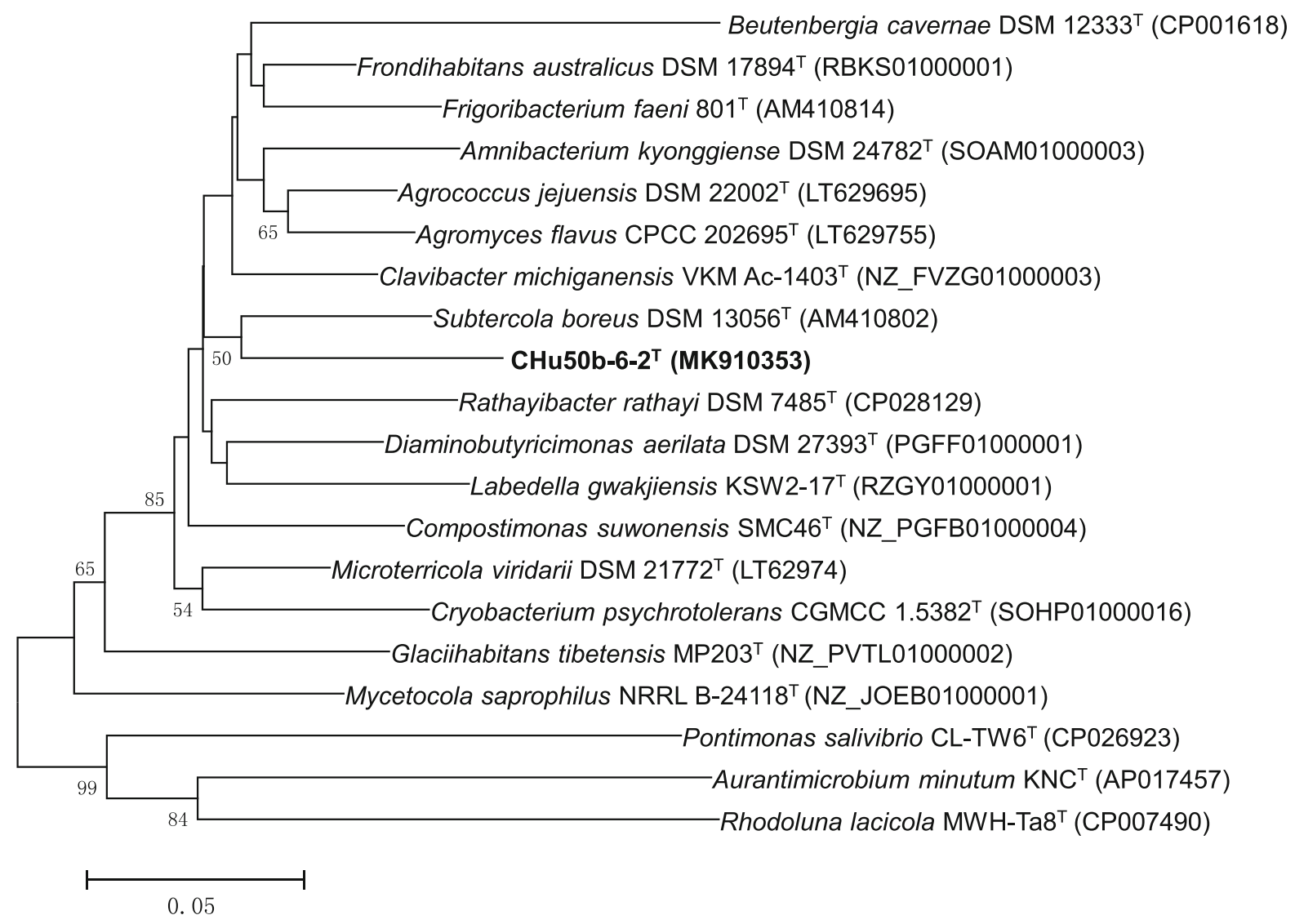

Fig. 2 Phylogenetic tree of $r e c \mathrm{~A}$ gene using maximumlikelihood method showing positions of strain CHu50b-6-2 $2^{\mathrm{T}}$ and related taxa. Beutenbergia cavernae DSM $12333^{\mathrm{T}}$

large amount of anteiso- $\mathrm{C}_{17: 0}(14.5 \%)$ compared to the closet members G. tibetensis KCTC $29148^{\mathrm{T}}$ (3.6\%), F. faeni $\mathrm{KACC} 20509^{\mathrm{T}}(5.1 \%)$ and $L$. cavernae DSM $27960^{\mathrm{T}}(1.8 \%)$, and a smaller amount of iso- $\mathrm{C}_{14: 0}$ (1.6\%) compared to L. cavernae DSM $27960^{\mathrm{T}}$ $(22.2 \%)$. Although the overall polar lipid patterns were very similar, there were some differences in the unidentified phospholipids and the unidentified lipids between CHu50b-6-2 $2^{\mathrm{T}}$ and the species G. tibetensis, $F$. faeni and L. cavernae. Strain CHu50b-6-2 $2^{\mathrm{T}}$ had B1 $\alpha$ type pepdidoglycan structure, which differed from phylogenetically related genera Glaciihabitans, Frigoribacterium, and Lysinibacter. Together with some other physiological results, it could be concluded that the strain CHu50b-6-2 $2^{\mathrm{T}}$ differs from the close species G. tibetensis, F. faeni and L. cavernae (Tables 1, 2). And also, strain CHu50b-6-2 $2^{\mathrm{T}}$ can be differentiated from closely related genera within the family $M i$ crobacteriaceae on the basis of its chemotaxonomic
(CP001618) was used as an outgroup. Bar, 5 substitutions per $100 \mathrm{nt}$. Only bootstrap values above $50 \%$ are shown (1000 resamplings) at branching points

characteristics such as fatty acids, polar lipids, menaquinones, and $\mathrm{G}+\mathrm{C}$ content (Table 3). Therefore, it should be considered that the strain is not accommodated in any of known genera within the family Microbacteriaceae.

On the basis of the phylogenetic position and genotypic, chemotaxonomic, and physiological differences, we propose that strain CHu50b-6-2 $2^{\mathrm{T}}$ should be assigned as a novel species within a new genus, Lacisediminihabitans gen. nov., with the name Lacisediminihabitans profunda sp. nov. within the family Microbacteriaceae.

The Digital Protologue database (Rosselló-Móra et al. 2017) TaxoNumber for type strain CHu50b-6-2 $2^{\mathrm{T}}$ is GA00113. 


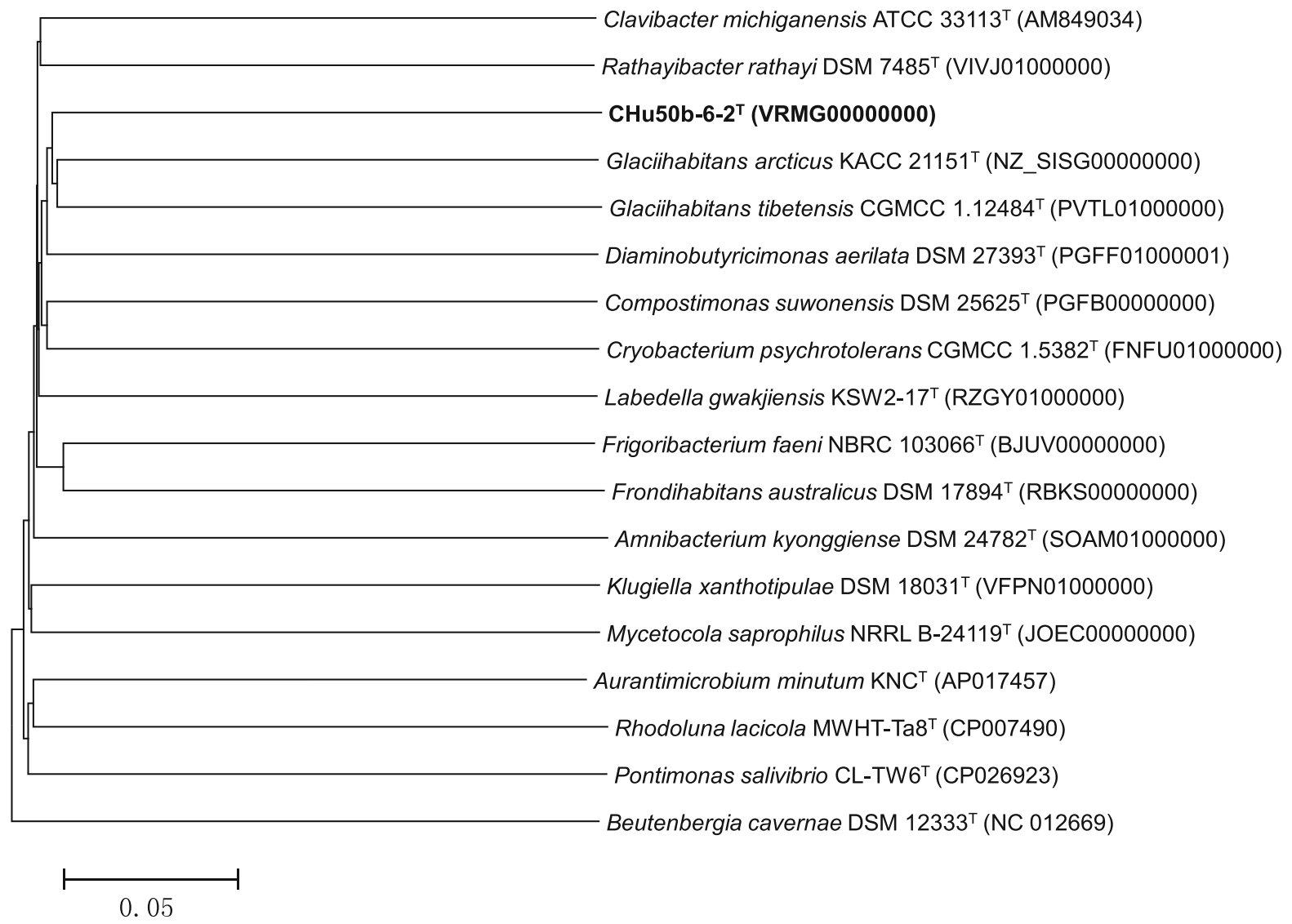

Fig. 3 UPGMA dendrogram based on ANI values of genomic sequences showing the positions of strain CHu50b-6-2 $2^{\mathrm{T}}$ among the type species within the family Microbacteriaceae.

Description of Lacisediminihabitans profunda gen. nov.

Lacisediminihabitans (La.ci.se.di.mi.ni.ha.bi’tans. L. n. lacus lake; L. n. sedimeninis sediment; L. masc. n. habitans an inhabitant; N.L. fem. n. Lacisediminihabitans an inhabitant of lake sediment).

Cells are observed to be Gram-stain-positive, nonspore-forming, non-motile and rod-shaped. The predominant respiratory menaquinone is MK-10. The major polar lipids are diphosphatidylglycerol (DPG), phosphatidylglycerol (PG), and an unidentified glycolipid (GL). The major fatty acids are anteiso- $\mathrm{C}_{15: 0}$, iso- $\mathrm{C}_{16: 0}$, and anteiso- $\mathrm{C}_{17: 0}$. The cell-wall peptidoglycan is $\mathrm{B} 1 \alpha$ contains 2, 4-diaminobutyric acid as the diagnostic diamino acid. Phylogenetically, the genus belongs to the family Microbacteriaceae in the class Actinobacteria, being closely related to the genera
Beutenbergia cavernae DSM $12333^{\mathrm{T}}$ was used as an outgroup. Beutenbergia cavernae DSM $12333^{\mathrm{T}}$ (NC 012669) was used as an outgroup. Bar, $5 \%$ difference in ANI value

Table 2 Cellular fatty acid compositions (\%) of strain CHu50b-6-2 $2^{\mathrm{T}}$ and related type strains

\begin{tabular}{lllll}
\hline Fatty acids & 1 & 2 & 3 & 4 \\
\hline Iso-C $_{14: 0}$ & 1.6 & 5.9 & 3.4 & 22.2 \\
Iso-C $_{13: 0} 3 \mathrm{OH}$ & $\operatorname{tr}$ & $\operatorname{tr}$ & 2.6 & $\operatorname{tr}$ \\
Anteiso-C $_{15: 1} \mathrm{~A}$ & 2.7 & 1.5 & $\operatorname{tr}$ & $\operatorname{tr}$ \\
Iso-C $_{15: 0}$ & 3.1 & 1.7 & 3.8 & 1.0 \\
Anteiso-C $_{15: 0}$ & 46.6 & 57.9 & 38.0 & 27.2 \\
Iso-C $_{14: 0} 3 \mathrm{OH}$ & $\operatorname{tr}$ & $\operatorname{tr}$ & 1.1 & $\operatorname{tr}$ \\
$\mathrm{C}_{14: 0} 2 \mathrm{OH}$ & $\operatorname{tr}$ & 4.2 & 17.0 & $\operatorname{tr}$ \\
Iso-C $_{16: 0}$ & 29.7 & 21.5 & 23.9 & 45.6 \\
$\mathrm{C}_{16: 0}$ & 1.3 & 2.7 & 3.1 & 1.6 \\
Anteiso-C & 14.5 & 3.6 & 5.1 & 1.8 \\
\hline
\end{tabular}

Strains: 1, CHu50b-6-2 $2^{\mathrm{T}} ; 2$, G. tibetensis KCTC $29148^{\mathrm{T}} ; 3, F$. faeni KACC $20509^{\mathrm{T}}$; 4, L. cavernae DSM $27960^{\mathrm{T}}$. All data were from present study. Cells of all strains were harvested after growth on R2A agar at $30{ }^{\circ} \mathrm{C}$ for $48 \mathrm{~h}$. tr, not detected or less than $1 \%$ 
Table 3 Differential characteristics of strain CHu50b-6-2 ${ }^{\mathrm{T}}$ and members of related genera in the family Microbacteriaceae

\begin{tabular}{|c|c|c|c|c|c|c|c|c|c|c|}
\hline Characteristics & 1 & 2 & 3 & 4 & 5 & 6 & 7 & 8 & 9 & 10 \\
\hline Pigmentation & Yellow & Yellow & Yellow & Yellow & Cream & $\begin{array}{l}\text { Coral, } \\
\text { yellow, } \\
\text { pink }\end{array}$ & Yellow & White & Yellow & $\begin{array}{l}\text { White, } \\
\text { yellow }\end{array}$ \\
\hline Motility & - & - & $\mathrm{v}$ & - & - & $\mathrm{v}$ & + & - & - & $\mathrm{v}$ \\
\hline $\begin{array}{r}\text { Diamino } \\
\operatorname{acid}(\mathrm{s})\end{array}$ & DAB & DAB & D-Lys & L-Lys & Lys & DAB & D-Orn & ${ }^{\mathrm{L}-} \mathrm{DAB}$ & Lys, Orn & Orn \\
\hline Peptidoglycan & $\mathrm{B} 1 \alpha$ & B10 & $\mathrm{B} 2 \beta$ & $\begin{array}{l}\text { unknow } \\
\text { peptidoglycan } \\
\text { structure }\end{array}$ & $\mathrm{B} 2 \beta$ & $\mathrm{B} 2 \gamma$ & $\mathrm{B} 2 \beta$ & B1 & B & $\mathrm{B} 2 \beta$ \\
\hline $\begin{array}{l}\text { Respiratory } \\
\text { quinones }\end{array}$ & MK-10 & $\begin{array}{l}\text { MK-9, } \\
10,11\end{array}$ & MK-9 & MK-9, 10, 11 & MK-9 & $\begin{array}{l}\text { MK-8, 9, } \\
10,11, \\
12\end{array}$ & $\begin{array}{c}\text { MK-9, } \\
10 \\
11 \\
12 \\
13\end{array}$ & $\begin{array}{c}\text { MK- } \\
11 \\
12\end{array}$ & $\begin{array}{l}\text { MK-10, } \\
11\end{array}$ & $\begin{array}{c}\text { MK-7, } \\
8,9\end{array}$ \\
\hline $\begin{array}{l}\text { Major polar } \\
\text { lipids }\end{array}$ & $\begin{array}{l}\text { DPG, } \\
\text { PG, } \\
\text { GL }\end{array}$ & $\begin{array}{l}\text { DPG, PG, } \\
\text { GL }\end{array}$ & $\begin{array}{l}\text { DPG, PG, } \\
\text { GL }\end{array}$ & $\begin{array}{l}\text { DPG, PG, GL, } \\
\text { PL, L }\end{array}$ & $\begin{array}{l}\text { DPG, } \\
\text { PG, } \\
\text { GL }\end{array}$ & $\begin{array}{l}\text { DPG, PG, } \\
\text { L }\end{array}$ & $\begin{array}{l}\text { DPG, } \\
\text { PG, } \\
\text { GL }\end{array}$ & $\begin{array}{l}\text { DPG, } \\
\text { PG, } \\
\text { GL }\end{array}$ & PG, DPG & PG, GL \\
\hline $\begin{array}{l}\text { DNA G }+\mathrm{C} \\
\text { content } \\
(\mathrm{mol} \%)\end{array}$ & 67.3 & $64.1-66.9$ & $68.2-71.0$ & 62.6 & 68 & $64.7-70$ & 66 & 68.0 & $61.0-63.5$ & $65.4-71$ \\
\hline
\end{tabular}

Taxa: 1, Strain CHu50b-6-2 ${ }^{\mathrm{T}}$ (from this study); 2, Glaciihabitans (Li et al. 2014; Dahal and Kim 2019); 3, Frigoribacterium (Kämpfer et al. 2000; Wang et al. 2015; Kong et al. 2016); 4, Lysinibacter (Tuo et al. 2015); 5, Parafrigoribacterium (Dastager et al. 2008a; Kong et al. 2016); 6, Cryobacterium (Suzuki et al. 1997; Dastager et al. 2008b; Liu et al. 2013, 2018); 7, Homoserinimonas (Kim et al. 2012a); 8, Compostimonas (Kim et al. 2012b); 9, Salinibacterium (Han et al. 2003; Zhang et al. 2008); 10, Frondihabitans (Zhang et al. 2007; Greene et al. 2009; Lee 2010; Cardinale et al. 2011; Kim et al. 2014). -, negative; +, positive; v, variable

DAB, 4-diaminobutyric acid; Lys, lysine; D-Orn, D-ornithine; DPG, diphosphatidylglycerol; PG, phosphatidylglycerol; GL, unidentified glycolipid; L, unidentified lipid

Glaciihabitans, Frigoribacterium, and Lysinibacter. The type species is Lacisediminihabitans profunda.

\section{Description of Lacisediminihabitans profunda sp.} nov.

Lacisediminihabitans profunda (pro.fun'da. L. fem. adj. profunda from the deep).

In addition to the characteristics described above, the novel species has the following properties. Colonies on R2A are convex, circular with entire edges and yellow color. The cells are observed to be oxidase-negative but catalase-positive. Growth occurs on R2A at temperatures from 4 to $30^{\circ} \mathrm{C}$ (optimum temperature $25-30{ }^{\circ} \mathrm{C}$ ), but not at $37{ }^{\circ} \mathrm{C}$. The $\mathrm{pH}$ range for growth is from $\mathrm{pH}$ 6-10 (optimum $\mathrm{pH} 7$ ); however, there is no growth at $\mathrm{pH} 5$ and 11 . No growth was observed on TSA, LB, and NA media. The cells are positive for nitrate reduction and $\beta$-galactosidase but negative for aesculin hydrolysis, indole production, glucose fermentation, urease, arginine dihydrolase or gelatin hydrolysis (API 20NE test strip). The $\mathrm{G}+\mathrm{C}$ content of the genomic DNA is $67.3 \mathrm{~mol} \%$.

The type strain is CHu50b-6-2 $2^{\mathrm{T}}$ (= KCTC $49081^{\mathrm{T}-}$ $=\mathrm{JCM} 32673^{\mathrm{T}}$ ) isolated from a $67-\mathrm{cm}$-long sediment core taken from the Daechung Reservoir, Republic of South Korea.

Acknowledgements This work was supported by the National Research Foundation of Korea (NRF) grant funded by the Korea government (MSIP; Ministry of Science, ICT and Future Planning) (NRF-2018R1C1B3009513) and the Priority Academic Program Development of Jiangsu Higher Education Institutions (PAPD).

Author contributions L.J. and H.G.L. designed the experiments; Y.Z. and C.Z.J. carried out the experiments; T.L., C.S.L., F.-J.J. and H.M.O. analyzed the results (phylogenetic and chemotaxonomic data); D.H.K. contributed to extract and analyze peptidoglycan and description and 
discussion of characteristics of the peptidoglycan; Y.Z. and L.J. wrote the manuscript.

\section{Compliance with ethical standards}

Conflict of interest The authors declare that the study was conducted in the absence of any commercial or financial relationships that could be constructed as a potential conflict of interest.

Open Access This article is distributed under the terms of the Creative Commons Attribution 4.0 International License (http:// creativecommons.org/licenses/by/4.0/), which permits unrestricted use, distribution, and reproduction in any medium, provided you give appropriate credit to the original author(s) and the source, provide a link to the Creative Commons license, and indicate if changes were made.

\section{References}

Bates RG, Bower VE (1956) Alkaline solutions for $\mathrm{pH}$ control. Anal Chem 28:1322-1324

Cardinale M, Grube M, Berg G (2011) Frondihabitans cladoniiphilus sp. nov., an actinobacterium of the family Microbacteriaceae isolated from lichen, and emended description of the genus Frondihabitans. Int J Syst Evol Microbiol 61:3033-3038

Dahal RH, Kim J (2019) Glaciihabitans arcticus sp. nov., a psychrotolerant bacterium isolated from Arctic soil. J Syst Evol Microbiol, Int. https://doi.org/10.1099/ijsem.0. 003520

Dastager SG, Lee JC, Ju YJ, Park DJ, Kim CJ (2008a) Frigoribacterium mesophilum sp. nov., a mesophilic actinobacterium isolated from Bigeum Island. Korea. Int J Syst Evol Microbiol 58:1869-1872

Dastager SG, Lee JC, Ju YJ, Park DJ, Kim CJ (2008b) Cryobacterium mesophilum sp. nov., a novel mesophilic bacterium. Int J Syst Evol Microbiol 58:1241-1244

Dias FF, Bhat JV (1962) A new levan producing bacterium, Corynebacterium laevaniformans nov. spec. Antonie Van Leeuwenhoek 28:63-72

Ezaki T, Hashimoto Y, Yabuuchi E (1989) Fluorometric deoxyribonucleic acid- deoxyribonucleic acid hybridization in microdilution wells as an alternative to membrane filter hybridization in which radioisotopes are used to determine genetic relatedness among bacterial strains. Int J Syst Bacteriol 39:224-229

Felsenstein J (1981) Evolutionary trees from DNA sequences: a maximum likelihood approach. J Mol Evol 17:368-376

Felsenstein J (1985) Confidence limit on phylogenies: an approach using the bootstrap. Evolution 39:783-791

Fitch WM (1971) Toward defining the course of evolution: minimum change for a specific tree topology. Syst Zool 20:406-416

Gomori G (1955) Preparation of buffers for use in enzyme studies. Methods Enzymol 1:138-146
Greene AC, Euzéby JP, Tindall BJ, Patel BK (2009) Proposal of Frondihabitans gen. nov. to replace the illegitimate genus name Frondicola Zhang et al. 2007. Int J Syst Evol Microbiol 59:447-4488

Han SK, Nedashkovskaya OI, Mikhailov VV, Kim SB, Bae KS (2003) Salinibacterium amurskyense gen. nov., sp. nov., a novel genus of the family Microbacteriaceae from the marine environment. Int $\mathbf{J}$ Syst Evol Microbiol 53:2061-2066

Hasegawa T, Takizawa M, Tanida S (1983) A rapid analysis for chemical grouping of aerobic actinomycetes. J Gen Appl Microbiol 29:319-322

Jang YH, Kim SJ, Hamada M, Tamura T, Ahn JH, Weon HY, Suzuki K, Kwon SW (2012) Diaminobutyricimonas aerilata gen. nov., sp. nov., a novel member of the family Microbacteriaceae isolated from an air sample in Korea. J Microbiol 50:1047-1052

Jin L, Lee HG, Kim HS, Ahn CY, Oh HM (2013) Amnibacterium soli sp. nov., an actinobacterium isolated from grass soil. Int J Syst Evol Microbiol 63:4750-4753

Jin L, Lee CS, Ahn CY, Lee HG, Lee S, Shin HH, Lim D, Oh HM (2017) Abundant iron and sulfur oxidizers in the stratified sediment of a eutrophic freshwater reservoir with annual cyanobacterial blooms. Sci Rep 7:43814

Kämpfer P, Rainey FA, Andersson MA, Nurmiaho Lassila EL, Ulrych U, Busse HJ, Weiss N, Mikkola R, SalkinojaSalonen M (2000) Frigoribacterium faeni gen. nov., sp. nov., a novel psychrophilic genus of the family $M i$ crobacteriaceae. Int J Syst Evol Microbiol 50:355-363

Katayama T, Kato T, Tanaka M, Douglas TA, Brouchkov A, Fukuda M, Tomita F, Asano K (2009) Glaciibacter superstes gen. nov., sp. nov., a novel member of the family Microbacteriaceae isolated from a permafrost ice wedge. Int J Syst Evol Microbiol 59:482-486

Kim SJ, Lee SS (2011) Amnibacterium kyonggiense gen. nov., sp. nov., a new member of the family Microbacteriaceae. Int J Syst Evol Microbiol 61:155-159

Kim KK, Lee KC, Oh HM, Lee JS (2008) Microbacterium aquimaris sp. nov., isolated from seawater. Int J Syst Evol Microbiol 58:1616-1620

Kim SJ, Jang YH, Hamada M, Tamura T, Ahn JH, Weon HY, Suzuki K, Kwon SW (2012a) Homoserinimonas aerilata gen. nov., sp. nov., a novel member of the family $M i$ crobacteriaceae isolated from an air sample in Korea. J Microbiol 50:673-679

Kim SJ, Tamura T, Hamada M, Ahn JH, Weon HY, Park IC, Suzuki K, Kwon SW (2012b) Compostimonas suwonensis gen. nov., sp. nov., isolated from spent mushroom compost. Int J Syst Evol Microbiol 62:2410-2416

Kim SJ, Lim JM, Ahn JH, Weon HY, Hamada M, Suzuki K, Ahn TY, Kwon SW (2014) Description of Galbitalea soli gen. nov., sp. nov., and Frondihabitans sucicola sp. nov. Int J Syst Evol Microbiol 64:572-578

Kimura M (1980) A simple method for estimating evolutionary rates of base substitutions through comparative studies of nucleotide sequences. J Mol Evol 16:111-120

Komagata K, Suzuki KI (1987) Lipid and cell wall analysis in bacterial systematics. Methods Microbiol 19:161-207

Kong D, Guo X, Zhou S, Wang H, Wang Y, Zhu J, Dong W, Li Y, He M, Hu G, Zhao B, Ruan Z (2016) Frigoribacterium salinisoli sp. nov., isolated from saline soil, transfer of 
Frigoribacterium mesophilum to Parafrigoribacterium gen. nov. as Parafrigoribacterium mesophilum comb. nov. Int J Syst Evol Microbiol 66:5252-5259

Kumar S, Stecher G, Tamura K (2016) MEGA7: molecular Evolutionary Genetics Analysis Version 7.0 for Bigger Datasets. Mol Biol Evol 33:1870-1874

Lai WA, Lin SY, Hameed A, Hsu YH, Liu YC, Huang HR, Shen FT, Young CC (2015) Leucobacter zeae sp. nov., isolated from the rhizosphere of maize (Zea mays L.). Int J Syst Evol Microbiol 65:4734-4742

Lane DJ (1991) 16S/23S rRNA sequencing. In: Stackebrandt E, Goodfellow M (eds) Nucleic acid techniques in bacterial systematics. Wiley, Chichester

Lee SD (2007) Labedella gwakjiensis gen. nov., sp. nov., a novel actinomycete of the family Microbacteriaceae. Int J Syst Evol Microbiol 57:2498-2502

Lee SD (2010) Frondihabitans peucedani sp. nov., an actinobacterium isolated from rhizosphere soil, and emended description of the genus Frondihabitans Greene et al. 2009. Int J Syst Evol Microbiol 60:1740-1744

Lee I, Ouk Kim Y, Park SC, Chun J (2016) OrthoANI: an improved algorithm and software for calculating average nucleotide identity. Int $\mathrm{J}$ Syst Evol Microbiol 66:1100-1103

Li AH, Liu HC, Xin YH, Kim SG, Zhou YG (2014) Glaciihabitans tibetensis gen. nov., sp. nov., a psychrotolerant bacterium of the family Microbacteriaceae, isolated from glacier ice water. Int J Syst Evol Microbiol 64:579-587

Liu Q, Liu H, Zhang J, Zhou Y, Xin Y (2013) Cryobacterium levicorallinum sp. nov., a psychrophilic bacterium isolated from glacier ice. Int J Syst Evol Microbiol 63:2819-2822

Liu Q, Xin YH, Chen XL, Liu HC, Zhou YG, Chen WX (2018) Cryobacterium aureum sp. nov., a psychrophilic bacterium isolated from glacier ice collected from the ice tongue surface. Int J Syst Evol Microbiol 68:1173-1176

Männistö MK, Schumann P, Rainey FA, Kämpfer P, Tsitko I, Tiirola MA, Salkinoja-Salonen MS (2000) Subtercola boreus gen. nov., sp. nov. and Subtercola frigoramans sp. nov., two new psychrophilic actinobacteria isolated from boreal groundwater. Int $\mathrm{J}$ Syst Evol Microbiol 50:1731-1739

Park YH, Suzuki K, Yim DG, Lee KC, Kim E, Yoon J, Kim S, Kho YH, Goodfellow M, Komagata K (1993-1994) Suprageneric classification of peptidoglycan group B actinomycetes by nucleotide sequencing of $5 \mathrm{~S}$ ribosomal RNA. Antonie van Leeuwenhoek 64:307-313

Park MH, Traiwan J, Jung MY, Kim W (2012) Gulosibacter chungangensis sp. nov., an actinomycete isolated from a marine sediment, and emended description of the genus Gulosibacter. Int J Syst Evol Microbiol 62:1055-1060

Parte AC (2018) LPSN-list of prokaryotic names with standing in nomenclature (bacterio.net), 20 years on. Int J Syst Evol Microbiol 68:1825-1829

Reddy GSN, Prakash JSS, Srinivas R, Matsumoto GI, Shivaji S (2003) Leifsonia rubra sp. nov. and Leifsonia aurea sp. nov., psychrophiles from a pond in Antarctica. Int J Syst Evol Microbiol 53:977-984

Ren TT, Jin CZ, Jin FJ, Li T, Kim CJ, Oh HM, Lee HG, Jin L (2018) Flavihumibacter profundi sp. nov., isolated from eutrophic freshwater sediment. J Microbiol 56:467-471
Rosselló-móra R, Trujillo ME, Sutcliffe IC (2017) Introducing a digital protologue: a timely move towards a database-driven systematics of archaea and bacteria. Syst Appl Microbiol 40:121-122

Saitou N, Nei M (1987) The neighbour-joining method; a new method for reconstructing phylogenetic trees. Mol Biol Evol 4:406-425

Schumann P, Zhang DC, Redzic M, Margesin R (2012) Alpinimonas psychrophila gen. nov., sp. nov., a novel actinobacterium of the family Microbacteriaceae isolated from alpine glacier cryoconite. Int J Syst Evol Microbiol 62:2724-2730

Shin NR, Kim MS, Jung MJ, Roh SW, Nam YD, Park EJ, Bae JW (2011) Leucobacter celer sp. nov., isolated from Korean fermented seafood. Int $\mathbf{J}$ Syst Evol Microbiol 61:2353-2357

Suzuki K, Sasaki J, Uramoto M, Nakase T, Komagata K (1997) Cryobacterium psychrophilum gen. nov., sp. nov., nom. rev., comb. nov., an obligately psychrophilic actinomycete to accommodate "Curtobacterium psychrophilum" Inoue and Komagata 1976. Int J Syst Bacteriol 47:474-478

Tamaoka J, Komagata K (1984) Determination of DNA base composition by reverse-phased high-performance liquid chromatography. FEMS Microbiol Lett 25:125-128

Tarrand JJ, Groschel DHM (1982) Rapid, modified oxidase test for oxidase-variable bacterial isolates. J Clin Microbiol 16:772-774

Thompson JD, Gibson TJ, Plewniak F, Jeanmougin F, Higgins DG (1997) The Clustal $X$ windows interface: flexible strategies for multiple sequence alignment aided by quality analysis tools. Nucleic Acids Res 24:4876-4882

Tindall BJ (1990) A comparative study of the lipid composition of Halobacterium saccharovorum from various sources. Syst Appl Microbiol 13:128-130

Tuo L, Guo L, Liu SW, Liu JM, Zhang YQ, Jiang ZK, Liu XF, Chen L, Zu J, Sun CH (2015) Lysinibacter cavernae gen. nov., sp. nov., a new member of the family Microbacteriaceae isolated from a karst cave. Int J Syst Evol Microbiol 65:3305-3512

Wang HF, Zhang YG, Chen JY, Guo JW, Li L, Hozzein WN, Zhang YM, Wadaan MA, Li WJ (2015) Frigoribacterium endophyticum sp. nov., an endophytic actinobacterium isolated from the root of Anabasis elatior (C. A. Mey.) Schischk. Int J Syst Evol Microbiol 65:1207-1212

Yoon SH, Ha SM, Kwon S, Lim J, Kim Y, Seo H, Chun J (2017) Introducing EzBioCloud: a taxonomically united database of 16S rRNA and whole genome assemblies. Int J Syst Evol Microbiol 67:1613-1617

Zhang L, Xu Z, Patel BK (2007) Frondicola australicus gen. nov., sp. nov., isolated from decaying leaf litter from a pine forest. Int J Syst Evol Microbiol 57:1177-1182

Zhang DC, Liu HC, Xin YH, Yu Y, Zhou PJ, Zhou YG (2008) Salinibacterium xinjiangense sp. nov., a psychrophilic bacterium isolated from the China No. 1 glacier. Int J Syst Evol Microbiol 58:2739-2742

Publisher's Note Springer Nature remains neutral with regard to jurisdictional claims in published maps and institutional affiliations. 